\title{
Fuzzy Language Translation in the Scenery Depiction-With Special Reference to Zhang Guruo's Translation of The Return of the Native
}

\author{
Yunli Zhao \\ Department of Foreign Languages, Shandong Jiaotong University, Jinan, China
}

\begin{abstract}
Language fuzziness is one of the features of human languages and the fiction language is no exception. This paper aims to analyze fuzzy language translation in the scenery depiction of The Return of the Native translated by Zhang Guruo. The three-character principle of translation formulated by Liu Zhongde functions as the yardstick to evaluate the translation referred to in this paper. The translation of personification and the proper use of addition are the two aspects expounded in this research.
\end{abstract}

Index Terms - fuzzy language, scenery depiction, the translation of personification, the proper use of addition

\section{INTRODUCTION}

Language fuzziness is one of the features of human languages. Bertrand Russell holds in his paper "Vagueness" that all language is more or less vague. (Wu, 1999, p.98) Just as Joanna Channell indicates, ordinary language leaves room for people to be vague, to avoid precision and the commitment associated with it.( Channel, 2000, p. X viii)Wang Peizhuang maintains in the preface to Fuzzy Linguistics written by Wu Tieping that language fuzziness ${ }^{1}$ is the intrinsic property of non-artificial languages ${ }^{2}$. (Wu, 1999, p.1)It is certain that language employed in fiction, one of the most essential and important form of literature, is no exception.

Bearing in mind that fuzziness is the inherent feature of language, this author focuses upon the translation of fuzzy language in scenery depiction in The Return of the Native as a research topic. Moreover, the three-character principle of translation formulated by Liu Zhongde, which is viewed as a useful criterion in evaluating the translated materials, will be an examiner in evaluating the translation exemplified in this paper.

\section{LiU Zhongde'S ThreE-Character Principle Of Translation AND THE RETURN OF the NATIVE}

The three-character principle of translation formulated by Liu Zhongde, which is viewed as a useful criterion in evaluating the translated materials, will be the basis of the evaluation of the translation referred to in this paper. In the recent decades, whenever the translation criterion is under discussion, the three characters "faithfulness, expressiveness and elegance" formulated by Yan Fu are thought of and hailed as the one and only maxim all translators observe. According to Liu Zhongde, the three principles formulated by Yan Fu for translation, especially some of the methods related to them, do not seem to be one hundred percent applicable to the translation works today. Liu, nevertheless, keeps the first two characters of Yan Fu's translation principle. He holds that what he means by being faithful to the content of the original amounts to what Yan Fu means by "the translation conforming to the original in meaning".(Liu, 1991, p.25)That is to say, the translator ought to convey the author's ideas faithfully and accurately. He has no right to alter the meaning of the original to suit his own taste. Having achieved faithfulness to the content of the original, the translator must aim at making his translation as expressive as the original, for it is intended for the reading public. In other words, the translation should be readable and understandable. It's just as Yan Fu said, "Without expressiveness, mere faithfulness would mean work to no avail."(Liu, 1991, p.25)Liu substitutes "closeness" for "elegance", because in his eyes elegance is actually one of various styles. A French naturalist, Buffon (1707-1788) makes the well-known statement that style is the man, meaning that style varies with authors. (Liu, 1991, p.26) Hence, translators should not make all their translations elegant in style. The original style must be exactly reproduced as it is. As a result, Liu employs the word "closeness", a neutral term which may be applied to all kinds of style. Liu also adds in his work that the Trinity Principle of Faithfulness, Expressiveness and Closeness constitutes an organic entirety. To put it another way, closeness always exhibits itself in the style. In "closeness" lie "faithfulness" and "expressiveness" and vice versa. "Faithfulness" is the prerequisite of "expressiveness" and "closeness"; "expressiveness" the representation of "faithfulness" and "closeness"; and "closeness" the very picture of "faithfulness" and "expressiveness". The three-in-one principle can never be overemphasized.( Liu, 1991, p.30-31)

\footnotetext{
1 This author must proclaim in advance that the two concepts in the paper are treated almost the same.

According to Webster's Online Dictionary, language that is deliberately created for a specific purpose is artificial language http://www.webster-dictionary.org/definition/\%20artificial\%20language
} 
The scenery depiction abounds in literary works, particularly in some classic British fiction. This author will discuss the translation of fuzzy language in the scenery depiction in literary works with special reference to Zhang Guruo's translation of The Return of the Native.

The Return of the Native is one of the masterly written works of Thomas Hardy. The great British novel in the $19^{\text {th }}$ century combines all of the great themes of Thomas Hardy's works. Wonderful descriptions of the English countryside underscore a rural tale of doomed love, passion, and melancholy. The whole story is dominated by the brooding presence of Egdon Heath and possibly in no other books does Hardy's extraordinary feeling for landscape blend so perfectly with his austere, stoic vision of human fate. That is the reason why Thomas Hardy categorizes The Return of the Native as "novels of character and environment". The novel opens with the famous portrait of Egdon Heath, the wild, haunted Wessex moor that D. H. Lawrence calls "the real stuff of tragedy" of the book. The heath's changing face mirrors the fortunes of the farmers, innkeepers, sons, mothers, and lovers that populate the novel. As a matter of fact, the first chapter of the novel is quite particular in style, that is, the depiction of scenery permeates all through every corner of it, no characters appearing. The scenery depiction of Egdon Heath in the first chapter demonstrates to readers the environment in which the story is set and drops readers a hint what is to happen to the main characters in the story. Nie Zhenzhao maintains that the portrait of Egdon Heath, together with the portrait of the Mississippi river by Mark Twain and London by Charles Dickens, is eminent delineation of environment in literature. (Li, 2000, p.11) The study of this chapter enables readers to believe that the art of the delineation of scenery in the literary works is largely the art of fuzzy language. As a result, this chapter will be excerpted in particular to illustrate the fuzzy language translation in the scenery depiction.

\section{The Translation Of Personification}

The most remarkable feature of the portrayal of Egdon Heath is the application of the personification, one kind of rhetoric. As already noted, personification is one form of fuzzy language, for it blurs the boundary between the human race and animated beings. The depiction of scenery in this chapter enables fuzzy language to exert its power and makes it possible for readers to allow full play to their imagination. Hence, readers can reconstruct the scenery of Egdon Heath in their mind. The first sentence of the first paragraph can help readers catch a glimpse:

A Saturday afternoon in November was approaching the time of twilight, and the vast tract of unenclosed wild known as Egdon Heath embrowned itself moment by moment.(Hardy, 1994, p.3)

Like the description of other novels, the first chapter opens with the setting of the story, that is, the time and the place. However, the distinction lies in the fact that the time and the place here are endowed with life and provided with consciousness and actions as well. In this sentence it is the two words "approach" and "embrown" that enliven the lifeless time and place. The time can approach "the time of twilight" and the place is able to make itself brown "moment by moment". In this sense, they possess the capacity of human beings. Regarding the translation of this sentence, another eminent translator has given the following rendering:

十一月一日一个星期六的下午，黄昏时分，那一片没有界篱隔断的广阔旷野——人们叫它“埃格登荒原”

也渐渐黯淡下来。( $\mathrm{Li}, 2000, \mathrm{p} .12$ )

Ostensibly the above translation is perfect, if measured using the yardstick of Liu Zhongde's three-character principle. But the actions which the two words "approaching" and "embrowned" are meant to convey are out of sight. Back to Zhang's translation, however, readers will marvel at the great translator's profound comprehension and excellent rendering.

十一月里的一个星期六的后半天, 越来越靠近暮色昏黄的时候了; 那一片没有垣篱界断的广大旷野, 提起来 都管它叫爱敦荒原的, 也一阵比一阵的凄迷苍茫。(Zhang, 1958, p.1)

In Zhang's translation, to retain the action which the first word is intended for, the fuzzy word "approaching" is put into Chinese as “靠近”. Seemingly, it is a pity that the other fuzzy word is translated as the Chinese fuzzy expression “凄迷苍茫”, which lacks the sense of motion. However, the Chinese phrase properly extends the implication of the English word "embrowned". In addition, taking the original as a whole, not only does Zhang' s translation faithfully convey the original idea, but also impresses readers with the charm of symmetry and balance of the sentence.

Another example is in the latter part of the second paragraph:

...it could in like manner retard the dawn, sadden noon, anticipate the frowning of storms scarcely generated, and intensify the opacity of a moonless midnight to a cause of shaking and dread. (Hardy, 1994, p.3)

Undoubtedly, the above sentence using the skill of personification can be regarded as a fuzzy one. It is employed to serve the depiction of Egdon Heath, enabling readers to have a vivid picture in their mind that the "vast tract of unenclosed wild" is terrific and surly. Zhang faithfully renders this sentence as follows:

它能在同样的情形下, 使曙色来的迟缓, 使正午变得凄冷; 狂风暴雨几乎还没踪影, 它就预先显示出风暴的 阴沉面目; 三更半夜, 没有月光, 它更加深那种只尺难辩的昏暗, 以至使人害怕发抖。(Zhang, 1958, p.3-4)

A most typical instance can refer to the first two sentences in the fourth paragraph:

The place became full of a watchful intentness now; for when other things sank brooding to sleep the heath appeared slowly to awake and listen. (Hardy, 1994, p.4)

No wonder that by using the underlined phrases everything including the heath is endowed with the characteristics of 
human beings. To retain the personification of the original, Zhang renders with success "became full of a watchful

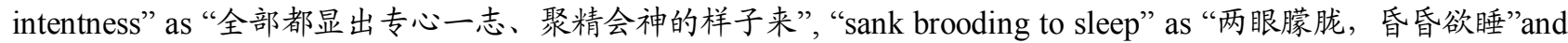
“slowly to awake and listen“ as “慢慢醒来，悄悄静听”.

Another wonderful instance of personification in this chapter can refer to the latter half of the third paragraph.

The spot was, indeed, a near relation of night, and when night showed itself an apparent tendency to gravitate together could be perceived in its shades and the scene. The somber stretch of rounds and hollows seemed to rise and meet the evening gloom, in pure sympathy, the heath exhaling darkness as rapidly as the heavens precipitated it. And so the obscurity in the air and the obscurity in the land closed together in a black fraternization towards which each advanced half- way. (Hardy, 1994, p.4)

这块地方实在和夜是近亲属; 只要夜一露面, 就显然能看出在夜色的苍冥里和荒原的景物上有一种相互凑合 的趋势: 那一片郁苍连绵的圆阜和空谷, 好像以十二分的同情, 起身迎接昏沉的暮色似的; 因为荒原一把黑夜 吐出, 天空也就把黑暗倾下, 两种动作都同样迅速。这样一来, 大气里的暝味和大地上的暝味, 就各走一半路 凑到了一起, 仿佛同枝连理, 结成一气氡氲。(Zhang, 1958, p.4)

In Zhang's version, such renderings as “近亲属”, “相互凑合”, “十二分的同情”, “起身迎接”, “各走一半路凑到了 一起”, “同枝连理” give readers an impression that the heath and the night portrayed in the novel possess the characteristics of human beings. They have their own feelings and emotions. Compared with the original, readers will notice that Zhang's translation is not only very close to the original in meaning but also brilliant and precise in the diction of the target language.

As Liu Zhongde noted, "true translation demands that the translator be faithful to the content, language and style of the original at the same time. By faithfulness to the content and style of the original, the translator must be true to its whole text, not to metaphrase individual phrases or sentences. Only by thus doing, can he come up to the standard of translation which conveys not only the meaning but also the spirit of the original work." Evidently, to achieve the aim of faithfulness, translators should contrive to retain the images in the target language. Zhang has just set an excellent example in translating the third sentence in the fourth paragraph:

Every night its Titanic form seemed to await something; but it had waited thus, unmoved, during so many centuries, through the crises of so many things, that it could only be imagined to await one last crisis - the final overthrow. (Hardy, 1994, p.4)

它那泰坦一般的形体, 每天夜里老仿佛在那儿等候一样东西似的。不过它那样一动不动地等候, 过了那么些 世纪了, 经历了那么些事情的危机了, 而它仍旧在那儿等候, 所以我们只能设想, 它是等候最末一次的危机, 等候天翻地覆的末日。(Zhang, 1958, p.4)

In the above sentence, "Titanic" is used as an adjective, meaning "of great force or power". It stems from the word "Titan". The following is the definition of "Titan" from Webster's Online Dictionary:

(Greek mythology) any of the primordial giant gods who ruled the Earth until overthrown by Zeus; the Titans were offspring of Uranus (Heaven) and Gaea (Earth).

This word, evidently, is meant not just to be a modifier conceiving the meaning "forceful or powerful". Its overriding importance rests upon the fact that it is assimilated to Egdon Heath. Therefore, “Titanic” is rendered as “泰坦一般的形 体”. In this sense, readers can perceive the fate and future of the heath, which functions as the metaphor of the society at that time. The last two words "the final overthrow" are a very good proof.

Actually, as far as the Heath is concerned, it does not merely serve as the background of the tragic story, but to a great extent it has become an embodiment of the powerful and eternal force of the nature, which is antagonistic to all human attempts to intrude upon it. It is generally recognized that the Heath is as strong a character as any in the novel-probably the strongest. It is the unique force that touches and molds all the lives dwelling upon it. Zhang's translation has justified his accurate comprehension. The above renderings convince readers to applaud the common belief that every living thing under Hardy's pen is endowed with flesh and blood.

\section{PROPER USE OF ADDITION}

As for the various concrete fuzzy language techniques in Zhang Guruo's translation of The Return of the Native, there are, of course, too many to enumerate and exhaust. Here, this author is going to introduce the most typical one-proper addition.

In many cases, it is neither possible nor necessary to translate word for word. Owing to the rich connotation of fuzzy expressions, in the process of translation, translators will, more often than not, have to make proper addition of some individual words in accordance with the corresponding laws inherent in the two languages concerned. Proper addition means supplying necessary words in the translation on the basis of an accurate comprehension of the original. According to Liu Zhongde, proper addition aims to retain and better express the original meaning. It is quite different from "random translation", which is subjectively and irresponsible to the original text. As has already been pointed out, a translation could not add any meaning to or subtract any meaning from the original work. However, this does not mean that a translator should refrain from supplying the necessary words to make his version both accurate in meaning and in keeping with the usage of the language to be translated into. In actual fact, it is just for the purpose of "faithful 
reproduction" that "proper addition" as a translation technique is frequently called for. For one thing, Chinese and English are two entirely different languages, with many a characteristic of their own, some being similar with each other, others different in form and content. For another, so far as fuzzy language translation is concerned, its rich connotation and blurred referential boundary make it possible to apply the technique of addition to fuzzy language translation. In Zhang's translation of the first chapter in The Return of the Native, the technique of addition is properly put into use. The second sentence in the first paragraph merits quoting:

Overhead the hollow stretch of whitish cloud shutting out the sky was as a tent which had the whole heath for its floor. (Hardy, 1994, p.3)

抬头看来, 弥漫长空的灰白浮云, 遮断了青天, 好像一座帐篷, 把整个荒原当作了它的地席。(Zhang, 1958, p.3)

Regarding the translation of the word "sky", apparently it is arbitrary to add a Chinese character “青”. But in fact it will be reasonable to render the word "sky" as “蓝”or “青”, for the "whitish cloud” is floating over the sky. Although the two fuzzy words “青” and “蓝” belong to neighboring color, to substitute “蓝” for “青” will totally change the original meaning. That is because the Chinese term “蓝天” matched with "the whitish cloud" tends to remind readers of a buoyant, lively and picturesque scenery. Bearing in mind that the depiction of the scenery in the first chapter is to unfold a tragic prelude for the reader, the version of “青天” will not whatsoever supply people with such a beautiful view and wonderful imagination. Similarly, “the whitish cloud” is translated as “灰白的浮云”. The Chinese fuzzy word “灰” is added to darken the tone of the depiction, which echoes the translation of "sky".

In actual fact, a scrutiny of Zhang's translation will convince readers that Zhang Guruo successfully practices two strategies for translating fuzzy language discussed in the this section, namely, fuzziness to fuzziness and preciseness to fuzziness. Examining the original and the Chinese version comparatively, this author, however, concludes that in most cases fuzziness to fuzziness strategy is frequently adopted. The following instance can make readers appreciate the translator's profound comprehension and the first-class translating skill:

Twilight combined with the scenery of Egdon Heath to evolve a thing majestic without severity, impressive without showiness, emphatic in its admonitions, grand in its simplicity. (Hardy, 1994, p.4)

苍苍的暮色和爱敦的景物，共同联合起来造出一种风光，堂皇而不严峻，感人而无粉饰，有深远的警戒性， 有浑厚的纯朴性。(Zhang, 1958, p.4-5)

As far as preciseness to fuzziness strategy is concerned, to put "pure” into Chinese as “十二分” is an excellent demonstration. In the following sentence from the sixth paragraph, the same fuzzy word "changed" is rendered respectively as “改易” “变迁” and “消长”. It can serve as another fantastic instance:

Distilled by the sun, kneaded by the moon, it is renewed in a year, in a day, or in an hour. The sea changed, the fields changed, the rivers, the villages, and the people changed, yet Egdon remained. (Hardy, 1994, p.7)

日光把它改易, 月华把它荡漾, 它的情形一年一样, 一天一样, 一时一刻一样。沧海改易, 桑田变迁, 江河 湖泽，村落人物，全有消长，但是爱敦荒原，却没有变化。（Zhang, 1958, p.8)

\section{CONCLUSION}

As has been exemplified above, not only does Zhang Guruo's version faithfully and expressively convey the meaning and the idea of the original, but it is quite close to its style. The Chinese version reads smoothly as if it was from the pen of a Chinese writer. It is universally acknowledged that the application of domestication is bound to harm the faithfulness. However, Zhang's version of this chapter convincingly proves the truth that both domestication and faithfulness can be gained provided that the translator is a well-cultured master of both the source and target languages.

\section{REFERENCES}

[1] Channel, Joanna. (2000). Vague Language. Shanghai: Shanghai Foreign Language Education Press.

[2] Hardy, Thomas . (1994).The Return of the Native. London: The Penguin Group.

[3] Li Yadan. (2000). Appreciation of English-Chinese Translation of Classic Novels. Wuhan: Hubei Education Press.

[4] Liu Zhongde. (1991). Ten Lectures on Literary Translation. Beijing: China Translation and Publishing Corporation.

[5] Wu Tieping. (1999). Fuzzy Linguistics. Shanghai: Shanghai Foreign Language Education Press.

[6] Zhang Guruo. (1958).The Return of the Native. Beijing: People's Literature Press.

Yunli Zhao was born in Shandong, China in 1971. He received his M.A. degree from Foreign Studies College of Shandong Normal University.

$\mathrm{He}$ is at present a lecturer in the Department of Foreign Languages, Shandong Jiaotong University, Jinan, China. His research interests include translation and American and British literature. 